\title{
Association of the CYP1A1 MspI and TNFa- 308 polymorphisms with chronic obstructive pulmonary disease in Inner Mongolia
}

\author{
L. Yang ${ }^{1 *}$, F. Li ${ }^{2 *}$, M. Yan ${ }^{1}$ and X. Su ${ }^{1}$ \\ ${ }^{1}$ Clinical Medical Research Center of the Affiliated Hospital, \\ Inner Mongolia Medical University, Huhhot, Inner Mongolia, China \\ ${ }^{2}$ Department of Geriatrics, Huhhot First Hospital, Huhhot, \\ Inner Mongolia, China \\ *These authors contributed equally to this study. \\ Corresponding author: X. Su \\ E-mail: xlsu2012@gmail.com
}

Genet. Mol. Res. 13 (2): 3209-3217 (2014)

Received January 24, 2013

Accepted July 19, 2013

Published April 25, 2014

DOI http://dx.doi.org/10.4238/2014.April.25.6

\begin{abstract}
Chronic obstructive pulmonary disease (COPD) is a progressive lung disease characterized by persistent airflow limitation. Smoking, occupational exposures, air pollution, and genetics are all risk factors. In the present study, we detected the cytochrome P4501A1 gene (CYP1A1) MspI polymorphism and the tumor necrosis factor alpha (TNF $\alpha$ )-308 single nucleotide polymorphism in COPD patients, and investigated their associations with smoking and COPD susceptibility in Inner Mongolia. A total of 101 COPD patients and 80 controls were enrolled in the study. The polymorphisms were analyzed using polymerase chain reaction-restriction fragment length polymorphism (PCR-RFLP). CYP1A1 MspI allele frequencies were significantly different between COPD patients and controls $(\mathrm{P}=0.033)$. COPD susceptibility was higher in subjects with the $\mathrm{m} 2$ allele compared to subjects with the $\mathrm{m} 1$ allele [odds ratio $(\mathrm{OR})=2.531,95 \%$ confidence interval $(\mathrm{CI})=1.297-4.940$, $\mathrm{P}=0.006]$. Significant differences were observed in the TNF $\alpha-308$
\end{abstract}


genotype and allele distributions between COPD patients and controls $(\mathrm{P}$ $=0.006$ and $\mathrm{P}=0.003$, respectively). Compared to subjects with the GG genotype, subjects with $\mathrm{GA}+\mathrm{AA}$ genotypes had higher $\mathrm{COPD}$ risk $(\mathrm{OR}=$ $3.639,95 \% \mathrm{CI}=1.576-8.403, \mathrm{P}=0.002$ ). The $\mathrm{TNF} \alpha-308$ polymorphism differed between smoking and non-smoking COPD patients and controls $(\mathrm{P}=0.047$ for genotype and $\mathrm{P}=0.030$ for allele). In conclusion, the CYP1A1 MspI and TNF $\alpha-308$ polymorphisms were associated with COPD susceptibility. Furthermore, of the two polymorphisms, only TNF $\alpha-308$ may exert an interaction with smoking.

Key words: CYP1A1; TNF $\alpha$; Polymorphism; Chronic obstructive pulmonary disease

\section{INTRODUCTION}

Chronic obstructive pulmonary disease (COPD) is a lung disease characterized by persistent airflow limitation that is usually progressive over time. COPD is the fourth leading cause of death worldwide, and the third in the United States of America. The economic burden of COPD in 2007 was $\$ 42.6$ billion, with respect to health care costs and loss of productivity. In China, COPD causes approximately $10 \%$ of deaths in urban areas, and $20 \%$ of deaths in rural areas (Qiao and Li, 2010). Tobacco smoking is the most common risk factor associated with COPD, with approximately $15 \%$ of smokers developing COPD (Fletcher and Peto, 1977). Non-smokers may also develop COPD, as occupational exposure, air pollution, and genetics are other risk factors. Deficiency of $\alpha$-1-antitrypsin is a recognized genetic risk factor contributing to the disease. Protease-antiprotease imbalance, oxidative stress, and inflammation have all been put forward as hypotheses for the pathogenesis of COPD. These mechanisms may act separately or in concert in the development of COPD.

The cytochrome P450 (CYP450) enzyme system family is a primary metabolic pathway for the metabolism of intrinsic and extrinsic compounds such as carcinogens and drugs (Gardiner and Begg, 2006). CYP450 genes are highly polymorphic, and mutations in different genes can result in altered, reduced, increased, or no enzyme activity or changes in the amount of enzymes (Zhou et al., 2009). CYP1A1 metabolizes several procarcinogens, including polycyclic aromatic hydrocarbons (PAHs) (Guengerich and Shimada, 1998). Smoking, air pollution, and certain occupations are notable sources of PAHs, and are risk factors for COPD (Butler et al., 1993). Several polymorphisms have been identified in CYP1A1; however, a thymine (T) to cytosine (C) substitution at the $M s p I$ site in the 3'-untranslated region (rs4646903) is commonly observed in Asian subjects. Although several studies have investigated the effect of the CYP1A1 MspI polymorphism on lung diseases, such as lung cancer and COPD, no clear consensus has yet been reached (Houlston, 2000; Cheng et al., 2009; Ji et al., 2012).

The tumor necrosis factor alpha $(\mathrm{TNF} \alpha)$ is a proinflammatory cytokine produced by activated macrophages, and can induce other inflammatory cytokines, chemokines, and growth factors (Wouters et al., 2009). Therefore, TNF $\alpha$ is thought to play a key role in the pathogenesis of COPD through tissue damage and remodeling (Churg et al., 2002; Mukhopadhyay et al., 2006). High concentrations of inflammatory mediators, such as TNF $\alpha$ and interleukins (IL)-6 and IL-8, are commonly found in peripheral blood of COPD patients (Franciosi et al., 2006; 
Higashimoto et al., 2008). A common guanine (G) to adenine (A) substitution at position 308 in the TNF $\alpha$ gene promoter (rs1800629) increases gene transcriptional activity (Wilson et al., 1997; Wu and McClain, 1997). This polymorphism has been studied with respect to COPD in several populations, again producing contradictory results (Higham et al., 2000; Sakao et al., 2001; Seifart et al., 2005; Brøgger et al., 2006; Chappell et al., 2007).

In the present study, we detected CYP1A1 MspI and TNF $\alpha-308$ polymorphisms in COPD patients, and explored the association between the polymorphisms, smoking, and COPD susceptibility in Inner Mongolia.

\section{MATERIAL AND METHODS}

\section{Subjects}

One hundred and one COPD patients and 80 control subjects were recruited from inpatients and outpatients of the Department of Respiratory of the Affiliated Hospital of Inner Mongolia Medical University and Huhhot First Hospital from 2008 to 2010. COPD was diagnosed according to the GOLD criteria: post-bronchodilator FEV1/FVC ratio $<70 \%$ without significant reversibility in the presence of respiratory symptoms. Control subjects underwent routine examinations, including spirometry and chest radiography or chest computed tomography (CT). Subjects diagnosed with chronic diseases (i.e., hypertension, diabetes, cancer) or other respiratory disease (i.e., bronchial asthma, bronchiectasis, tuberculosis) were excluded from the study. The following data were recorded for each subject: name, age, gender, occupation, smoking status, history of familial diseases, and exposure to carcinogens. All subjects gave informed consent. Our study was approved by the Inner Mongolia Medical University Affiliated Hospital Ethics Committee.

\section{DNA extraction and polymerase chain reaction-restricted fragment length polymorphism (PCR-RFLP) analysis}

Two milliliter peripheral venous blood was drawn from overnight fasted subjects into sodium citrate solution, and then stored at $-80^{\circ} \mathrm{C}$. Genomic DNA was extracted with the BloodGen Mini Kit (CWBIO, Beijing, China). The polymorphisms CYP1A1 MspI and TNF $\alpha-308$ were analyzed using PCR-RFLP. PCR was performed in a $25 \mu$ Lvolume including $8 \mu \mathrm{LddH}_{2} \mathrm{O}, 12.5 \mu \mathrm{L} 2 \mathrm{XTaq}$ MasterMix (CWBIO), $0.25 \mu \mathrm{L} 10 \mu \mathrm{M}$ CYPIA1 primer (sense 5'-CAG TGAAGAGGTGTAGCCGC-3' and antisense 5'-TAGGAGTCTTGTCTCATGCC-3') or TNF $\alpha$ primer (sense 5'-AGGCAATAGG TTTTGAGGGCCAT-3' and antisense 5'-GAGCGTCTGCTGGCTGGGTG-3'), and $4 \mu \mathrm{L}$ template DNA. The reaction conditions were as follows: initial denaturation at $95^{\circ} \mathrm{C}$ for $5 \mathrm{~min}$, followed by 35 cycles of degeneration at $94^{\circ} \mathrm{C}$ for $30 \mathrm{~s}$, reannealing at $61^{\circ} \mathrm{C}\left(\mathrm{TNF} \alpha\right.$ primer at $\left.62^{\circ} \mathrm{C}\right)$ for $30 \mathrm{~s}$, and extension at $72^{\circ} \mathrm{C}$ for $45 \mathrm{~s}$; with a final extension at $72^{\circ} \mathrm{C}$ for $7 \mathrm{~min}$. PCR products were digested with $M s p I$ and $N c o I$ (Fermentas, USA) for CYP1Al and TNFo, respectively, in a $37^{\circ} \mathrm{C}$ water bath for $4 \mathrm{~h}$. Ten-microliter digestion products were electrophoresed on $4 \%$ agarose gel at $80 \mathrm{~V}$ for $30 \mathrm{~min}$ and analyzed with a Gel-Pro imaging instrument.

The DNA fragment of the CYP1A1 gene was $340 \mathrm{bp}$ after PCR amplification with the primer. The expected sizes of the products after digestion with $M s p$ I were the following: homozygous wild-type $(\mathrm{m} 1 / \mathrm{m} 1)$ without a restriction site and an electrophoresis band of 340 bp; mutant homozygote $(\mathrm{m} 2 / \mathrm{m} 2)$ with a restriction site in each DNA chain, resulting in elec- 
trophoresis bands of 200 and $140 \mathrm{bp}$; and heterozygote $(\mathrm{m} 1 / \mathrm{m} 2)$ with restriction sites in one of the DNA chains, resulting in three electrophoresis bands at 340, 200, and $140 \mathrm{bp}$.

The DNA fragment of the TNF $\alpha$ gene was 345 bp after PCR amplification with the primer. Homozygous wild types (GG), containing restriction sites in each DNA chain, produced two fragments of 325 and $20 \mathrm{bp}$ after being digested with NcoI. Homozygotic mutants (AA) without a restriction site produced only one fragment of $345 \mathrm{bp}$. Heterozygotes (GA) containing restriction sites in one of the DNA chains produced three fragments of 345, 325, and $20 \mathrm{bp}$.

\section{Statistical analysis}

Statistical analysis was performed with the SPSS13.0 software. The chi-squared test or the Student $t$-test was performed to compare demographics and clinical characteristics between COPD patients and controls. The chi-squared test or Fisher's exact test were used to compare frequencies of genotypes and alleles between each group, and the chisquared test was used to identify whether individual variants deviated from Hardy-Weinberg equilibrium. Logistic regression was used to investigate correlations among smoking, CYP1A1 MspI, and the TNFa-308 polymorphism with COPD. Statistical significance was established at $\mathrm{P}<0.05$.

\section{RESULTS}

\section{Clinical characteristics of COPD patients and controls}

Demographics, lung function, and smoking status of COPD patients and controls are presented in Table 1. COPD patients and controls showed no difference in age or gender $(\mathrm{P}=$ 0.190 and $\mathrm{P}=0.191$, respectively). As expected, COPD patients had significantly limited airflow compared to controls $(\mathrm{P}<0.001)$. There were more smokers among COPD patients than among controls $(\mathrm{P}=0.026)$. We divided subjects into four groups according to smoking index $(<1,1-400,400-800,>800)$; COPD patients and controls showed no difference in smoking index $(\mathrm{P}=0.173)$. Compared to non-smokers, smokers had a greater risk in developing COPD [odds ratio $(\mathrm{OR})=2.198,95 \%$ confidence interval $(\mathrm{CI}): 1.138-4.245, \mathrm{P}=0.019$ ].

\section{Table 1. Demographics, lung function, and smoking status between controls and COPD patients.}

\begin{tabular}{lccr}
\hline & Controls $(\mathrm{N}=80)$ & COPD $(\mathrm{N}=101)$ & $\mathrm{P}$ \\
\hline Age (years) & $69.50 \pm 6.43$ & $68.24 \pm 6.34$ & 0.190 \\
Gender (M/F) & $54 / 26$ & $77 / 24$ & 0.192 \\
FEV1 (L) & $2.18(1.29)$ & $0.72(0.46)$ & $<0.001$ \\
FVC (L) & $2.62(1.49)$ & $1.33(0.77)$ & $<0.001$ \\
FEV1/FVC ratio & $81.88(5.74)$ & $46.79(13.74)$ & 0.001 \\
Smoking & $46(57.50)$ & $74(73.27)$ & 0.026 \\
Smoking index & $34(42.50)$ & $27(26.73)$ & 0.173 \\
$<1$ & $5(6.25)$ & $9(8.91)$ & \\
$1-400$ & $16(20.00)$ & $27(26.73)$ & \\
$401-800$ & $25(31.25)$ & $38(37.63)$ & \\
$>800$ & & & \\
\hline
\end{tabular}

Data are reported as means \pm standard deviation, median (quartile range), or number (percentage). $\mathrm{M} / \mathrm{F}=\mathrm{male} /$ female; FEV1 = forced expiratory volume in the first second; FVC = forced vital capacity; OR = odds ratio; $95 \% \mathrm{CI}=95 \%$ confidence interval. 


\section{Distribution of the CYP1A1 MspI and TNFa-308 polymorphisms in COPD patients and controls}

We observed that the CYP1A1 MspI and TNF $\alpha-308$ genotype distributions were in accordance with Hardy-Weinberg expectations in subjects $(\mathrm{P}>0.05)$. This demonstrated that the study groups were representative of the population.

The genotype and allele frequencies of the CYP1A1 MspI and TNF $\alpha-308$ polymorphisms are shown in Table 2. The CYP1A1 MspI genotypes $\mathrm{m} 1 / \mathrm{m} 1, \mathrm{~m} 1 / \mathrm{m} 2$, and $\mathrm{m} 2 / \mathrm{m} 2$ comprised $27.72,48.51$, and $23.76 \%$ of the COPD patients and $43.75,38.75$, and $17.50 \%$ of the controls, respectively $(\mathrm{P}=0.078)$. The $\mathrm{m} 1$ and $\mathrm{m} 2$ allele frequencies were 51.98 and $48.02 \%$ in COPD patients and 63.13 and $36.87 \%$ in controls, respectively $(\mathrm{P}=0.033)$. COPD susceptibility was higher in subjects with the $\mathrm{m} 2$ allele compared to subjects with the $\mathrm{m} 1$ allele (OR $=2.531,95 \% \mathrm{CI}=1.297-4.940, \mathrm{P}=0.006)$.

\begin{tabular}{|c|c|c|c|}
\hline & Controls $(\mathrm{N}=80)$ & $\operatorname{COPD}(\mathrm{N}=101)$ & $P$ \\
\hline \multicolumn{4}{|c|}{ CYP1A1 MSPI } \\
\hline \multicolumn{4}{|c|}{ Genotype } \\
\hline $\mathrm{m} 1 / \mathrm{m} 1$ & $35(43.75)$ & $28(27.72)$ & \\
\hline $\mathrm{m} 1 / \mathrm{m} 2$ & $31(38.75)$ & $49(48.51)$ & \\
\hline $\mathrm{m} 2 / \mathrm{m} 2$ & $14(17.50)$ & $24(23.76)$ & 0.078 \\
\hline \multicolumn{4}{|l|}{ Allele } \\
\hline $\mathrm{m} 1$ & $101(63.13)$ & $105(51.98)$ & \\
\hline $\mathrm{m} 2$ & $59(36.87)$ & 97 (48.02) & 0.033 \\
\hline \multicolumn{4}{|l|}{ TNF $\alpha 308$} \\
\hline \multicolumn{4}{|l|}{ Genotype } \\
\hline $\mathrm{G} / \mathrm{G}$ & $71(88.75)$ & $73(72.28)$ & \\
\hline $\mathrm{G} / \mathrm{A}$ & $9(11.25)$ & $25(24.75)$ & \\
\hline $\mathrm{A} / \mathrm{A}$ & $0(0)$ & $3(2.97)$ & $0.006^{\dagger}$ \\
\hline \multicolumn{4}{|l|}{ Allele } \\
\hline $\mathrm{G}$ & $151(94.38)$ & $171(84.65)$ & \\
\hline A & $9(5.62)$ & $31(15.35)$ & 0.003 \\
\hline
\end{tabular}

The TNF $\alpha-308$ GG, GA, and AA genotype frequencies were 72.28, 24.75, and $2.97 \%$ in COPD patients, and were $88.75,11.25$, and $0 \%$ in controls, respectively $(\mathrm{P}=$ 0.006). The $\mathrm{G}$ and $\mathrm{A}$ allele frequencies were 84.65 and $15.35 \%$ in COPD patients and 94.38 and $5.62 \%$ in controls, respectively $(\mathrm{P}=0.003)$. Compared to subjects with the GG genotype, subjects with GA+AA genotypes had higher $\mathrm{COPD}$ risk $(\mathrm{OR}=3.639,95 \% \mathrm{CI}=$ 1.576-8.403, $\mathrm{P}=0.002)$.

Previous studies have demonstrated that smoking is a risk factor of COPD. We investigated the association of the CYP1A1 MspI and TNF $\alpha-308$ polymorphisms with COPD between smoking and non-smoking subjects. There was no difference in the CYP1A1 MspI polymorphism between smoking and non-smoking COPD patients and controls $(\mathrm{P}=0.329$ for genotypes and $\mathrm{P}=0.134$ for alleles; Table 3 ). The $\mathrm{TNF} \alpha-308$ polymorphism genotypes showed a marginally significant difference between smoking and non-smoking COPD patients and controls $(\mathrm{P}=0.047)$, and allele distributions were significantly different $(\mathrm{P}=$ 0.030; Table 3). 


\begin{tabular}{|c|c|c|c|c|c|}
\hline & $\begin{array}{c}\text { Non-smoking } \\
\text { controls }(\mathrm{N}=34)\end{array}$ & $\begin{array}{l}\text { Smoking controls } \\
\quad(\mathrm{N}=46)\end{array}$ & $\begin{array}{c}\text { Non-smoking COPD } \\
(\mathrm{N}=27)\end{array}$ & $\begin{array}{l}\text { Smoking COPD } \\
\quad(\mathrm{N}=74)\end{array}$ & $\mathrm{P}$ \\
\hline \multicolumn{6}{|c|}{ CYP1A1 MSPI } \\
\hline \multicolumn{6}{|c|}{ Genotype } \\
\hline $\mathrm{m} 1 / \mathrm{m} 1$ & $15(44.12)$ & $20(43.48)$ & $5(18.52)$ & $23(31.08)$ & \\
\hline $\mathrm{m} 1 / \mathrm{m} 2$ & $12(35.29)$ & $19(41.30)$ & $15(55.55)$ & $34(45.95)$ & \\
\hline $\mathrm{m} 2 / \mathrm{m} 2$ & $7(20.59)$ & $7(15.22)$ & $7(25.93)$ & $17(22.97)$ & 0.329 \\
\hline \multicolumn{6}{|l|}{ Allele } \\
\hline $\mathrm{m} 1$ & $42(61.76)$ & 59 (64.13) & $25(46.30)$ & $80(54.05)$ & \\
\hline $\mathrm{m} 2$ & $26(38.24)$ & $33(35.87)$ & $29(53.70)$ & $68(45.95)$ & 0.134 \\
\hline \multicolumn{6}{|l|}{ rNFa 308} \\
\hline \multicolumn{6}{|l|}{ Genotype } \\
\hline $\mathrm{G} / \mathrm{G}$ & $29(85.29)$ & $42(91.30)$ & $20(74.07)$ & $53(71.62)$ & \\
\hline $\mathrm{G} / \mathrm{A}$ & $5(14.71)$ & $4(8.70)$ & $6(22.22)$ & $19(25.68)$ & \\
\hline $\mathrm{A} / \mathrm{A}$ & $0(0)$ & $0(0)$ & $1(3.71)$ & $2(2.70)$ & $0.047^{\dagger}$ \\
\hline \multicolumn{6}{|l|}{ Allele } \\
\hline G & $63(92.65)$ & $88(95.65)$ & $46(85.19)$ & $125(84.46)$ & \\
\hline A & $5(7.35)$ & $4(4.35)$ & $8(14.81)$ & $23(15.54)$ & 0.030 \\
\hline
\end{tabular}

Data are reported as number (percentage). ${ }^{\dagger}$ Genotype $\mathrm{G} / \mathrm{A}+\mathrm{A} / \mathrm{A}$ compared to $\mathrm{G} / \mathrm{G}$.

\section{DISCUSSION}

COPD is characterized by local and systemic oxidative stress and chronic inflammation. The sources of oxidative stress originate from inhaled oxidants such as cigarette smoke and air pollution, and from reactive oxygen species generated by inflammatory cells. Increasing evidence suggests that genetic factors may also play a role in the pathogenesis of COPD, particularly antioxidant genes. CYP1A1 belongs to the CYP450 family and participants in the metabolism of several procarcinogens. Associations between the CYP1A1 MspI polymorphism and several types of lung diseases, including lung cancer and COPD, have been investigated, but with controversial results. An association between lung cancer and the CYP1A1 MspI polymorphism was found in a Japanese population (Kawajiri et al., 1990; Nakachi et al., 1991), but not in Norwegian (Tefre et al., 1991), Finnish (Hirvonen et al., 1992), or American (Shields et al., 1993) populations. This may be related to the relatively lower $\mathrm{m} 2$ allele frequency observed in Caucasian control subjects (approximately 14\%) compared to a frequency of $33 \%$ in the Japanese population. The $\mathrm{m} 2$ allele frequency in the controls of the present study was $36.87 \%$, which is similar to that of the Japanese population and higher than that of Caucasian populations. Studies investigating the relationship between the CYP1A1 MspI polymorphism and COPD are scarce. Our results found no difference in genotype frequencies of the CYP1A1 MspI polymorphism between COPD patients and controls $(\mathrm{P}=0.078)$, and similar results were reported in a study in a Taiwanese population (Cheng et al., 2009). In the present study, COPD susceptibility was found to be higher in subjects carrying the $\mathrm{m} 2$ allele compared to subjects with the $\mathrm{m} 1$ allele $(\mathrm{OR}=2.531,95 \% \mathrm{CI}=1.297-4.940, \mathrm{P}=0.006)$. To confirm our results, the study should be repeated with larger samples in the future.

Chronic inflammation is also a key factor that contributes to COPD. Increased levels of inflammatory proteins, such as IL-6, C-reactive protein, and TNF $\alpha$, have been linked to COPD (Gan et al., 2004; Garcia-Rio et al., 2010; Pelegrino et al., 2013). Studies have shown that TNF $\alpha$ plays roles in weight loss and muscle reduction in COPD patients (Takabatake et al., 2000; Eid et al., 2001; Higashimoto et al., 2008). Increased TNFa is secreted from active 
macrophages through chronic inflammation. Furthermore, a single nucleotide polymorphism at position 308 of the TNF $\alpha$ gene promoter results in elevated gene expression. In the present study, TNFa-308 genotype and allele frequencies were significantly different between COPD patients and controls $(\mathrm{P}=0.006$ and $\mathrm{P}=0.003$, respectively). Moreover, there was a difference in the TNF $\alpha-308$ polymorphism between smoking and non-smoking COPD patients and controls ( $\mathrm{P}=0.047$ for genotypes and $\mathrm{P}=0.030$ for alleles), indicating that the TNF $\alpha-308$ polymorphism might interact with tobacco consumption. Smoking status has previously been shown to have a potential influence on TNFa levels (Tanni et al., 2010). Studies in Taiwanese (Huang et al., 1997), Japanese (Sakao et al., 2001), and Caucasian smokers (Gingo et al., 2008) showed similar results to those of the present study in demonstrating that the TNF $\alpha-308$ polymorphism is a risk factor of COPD. However, studies in Thai (Chierakul et al., 2005), adenovirus C-infected Egyptian (Ezzeldin et al., 2012), Caucasian (Higham et al., 2000; Chappell et al., 2007), German (Seifart et al., 2005), and European-descended American (Tanaka et al., 2007) subjects showed opposite results. Teramoto et al. (2008) stated that the TNF $\alpha-308$ polymorphism was not associated with susceptibility to Asian COPD. Recently, two metaanalyses found that the association of the TNF $\alpha-308$ polymorphism and COPD was statistically significant in Asian but not in Caucasian populations, for both the entire and only the smoking population (Zhan et al., 2011; Zhang et al., 2011). Another meta-analysis also confirmed that there was no association between the TNF $\alpha-308$ polymorphism and COPD in Caucasian populations (Brøgger et al., 2006). The two more recent meta-analyses were based on more studies than Teramoto et al. (2008), and in particular, included studies from the Chinese National Knowledge Infrastructure (CNKI) database, which might explain their controversial conclusions about the TNF $\alpha-308$ polymorphism and COPD in Asians.

In summary, subjects with the CYP1A1 MspI m2 allele or the TNF $\alpha-308$ A allele had higher COPD susceptibility $(\mathrm{OR}=2.531,95 \% \mathrm{CI}=1.297-4.940, \mathrm{P}=0.006$ and $\mathrm{OR}=3.639$, $95 \% \mathrm{CI}=1.576-8.403, \mathrm{P}=0.002$, respectively). However, only the $\mathrm{TNF} \alpha-308$ polymorphism, and not the CYP1A1 MspI polymorphism, might exert an interaction with smoking.

\section{ACKNOWLEDGMENTS}

Research supported by the National Natural Science Foundation of China (\#81260058).

\section{REFERENCES}

Brøgger J, Steen VM, Eiken HG, Gulsvik A, et al. (2006). Genetic association between COPD and polymorphisms in TNF, ADRB2 and EPHX1. Eur. Respir. J. 27: 682-688.

Butler JP, Post GB, Lioy PJ, Waldman JM, et al. (1993). Assessment of carcinogenic risk from personal exposure to benzo(a)pyrene in the Total Human Environmental Exposure Study (THEES). Air Waste 43: 970-977.

Chappell S, Daly L, Morgan K, Baranes TG, et al. (2007). Variation in the tumour necrosis factor gene is not associated with susceptibility to COPD. Eur. Respir. J. 30: 810-812.

Cheng SL, Yu CJ and Yang PC (2009). Genetic polymorphisms of cytochrome p450 and matrix metalloproteinase in chronic obstructive pulmonary disease. Biochem. Genet. 47: 591-601.

Chierakul N, Wongwisutikul P, Vejbaesya S and Chotvilaiwan K (2005). Tumor necrosis factor-alpha gene promoter polymorphism is not associated with smoking-related COPD in Thailand. Respirology 10: 36-39.

Churg A, Dai J, Tai H, Xie C, et al. (2002). Tumor necrosis factor-alpha is central to acute cigarette smoke-induced inflammation and connective tissue breakdown. Am. J. Respir. Crit. Care Med. 166: 849-854.

Eid AA, Ionescu AA, Nixon LS, Lewis-Jenkins V, et al. (2001). Inflammatory response and body composition in chronic obstructive pulmonary disease. Am. J. Respir. Crit. Care Med. 164: 1414-1418. 
Ezzeldin N, Shalaby A, Saad-Hussein A, Ezzeldin H, et al. (2012). Association of TNF-alpha -308G/A, SP-B 1580 C/T, IL-13 -1055 C/T gene polymorphisms and latent adenoviral infection with chronic obstructive pulmonary disease in an Egyptian population. Arch. Med. Sci. 8: 286-295.

Fletcher C and Peto R (1977). The natural history of chronic airflow obstruction. Br. Med. J. 1: 1645-1648.

Franciosi LG, Page CP, Celli BR, Cazzola M, et al. (2006). Markers of disease severity in chronic obstructive pulmonary disease. Pulm. Pharmacol. Ther. 19: 189-199.

Gan WQ, Man SF, Senthilselvan A and Sin DD (2004). Association between chronic obstructive pulmonary disease and systemic inflammation: a systematic review and a meta-analysis. Thorax 59: 574-580.

Garcia-Rio F, Miravitlles M, Soriano JB, Munoz L, et al. (2010). Systemic inflammation in chronic obstructive pulmonary disease: a population-based study. Respir. Res. 11: 63.

Gardiner SJ and Begg EJ (2006). Pharmacogenetics, drug-metabolizing enzymes, and clinical practice. Pharmacol. Rev. 58: 521-590.

Gingo MR, Silveira LJ, Miller YE, Friedlander AL, et al. (2008). Tumour necrosis factor gene polymorphisms are associated with COPD. Eur. Respir. J. 31: 1005-1012.

Guengerich FP and Shimada T (1998). Activation of procarcinogens by human cytochrome P450 enzymes. Mutat. Res. 400: 201-213.

Higashimoto Y, Yamagata Y, Taya S, Iwata T, et al. (2008). Systemic inflammation in chronic obstructive pulmonary disease and asthma: Similarities and differences. Respirology 13: 128-133.

Higham MA, Pride NB, Alikhan A and Morrell NW (2000). Tumour necrosis factor-alpha gene promoter polymorphism in chronic obstructive pulmonary disease. Eur. Respir. J. 15: 281-284.

Hirvonen A, Husgafvel-Pursiainen K, Karjalainen A, Anttila S, et al. (1992). Point-mutational MspI and Ile-Val polymorphisms closely linked in the CYP1A1 gene: lack of association with susceptibility to lung cancer in a Finnish study population. Cancer Epidemiol. Biomarkers Prev. 1: 485-489.

Houlston RS (2000). CYP1A1 polymorphisms and lung cancer risk: a meta-analysis. Pharmacogenetics 10: 105-114.

Huang SL, Su CH and Chang SC (1997). Tumor necrosis factor-alpha gene polymorphism in chronic bronchitis. Am. J. Respir. Crit. Care Med. 156: 1436-1439.

Ji YN, Wang Q, Lin XQ and Suo LJ (2012). CYP1A1 MspI polymorphisms and lung cancer risk: an updated meta-analysis involving 20,209 subjects. Cytokine 59: 324-334.

Kawajiri K, Nakachi K, Imai K, Yoshii A, et al. (1990). Identification of genetically high risk individuals to lung cancer by DNA polymorphisms of the cytochrome P450IA1 gene. FEBS Lett. 263: 131-133.

Mukhopadhyay S, Hoidal JR and Mukherjee TK (2006). Role of TNFalpha in pulmonary pathophysiology. Respir. Res. 7: 125 .

Nakachi K, Imai K, Hayashi S, Watanabe J, et al. (1991). Genetic susceptibility to squamous cell carcinoma of the lung in relation to cigarette smoking dose. Cancer Res. 51: 5177-5180.

Pelegrino NR, Tanni SE, Amaral RA, Angeleli AY, et al. (2013). Effects of active smoking on airway and systemic inflammation profiles in patients with chronic obstructive pulmonary disease. Am. J. Med. Sci. 345: 440-445.

Qiao CX and Li SY (2010). Current epidemiologic study on chronic obstructive pulmonary disease. Chin. J. Gerontol. 30: 1618-1621.

Sakao S, Tatsumi K, Igari H, Shino Y, et al. (2001). Association of tumor necrosis factor alpha gene promoter polymorphism with the presence of chronic obstructive pulmonary disease. Am. J. Respir. Crit. Care Med. 163: 420-422.

Seifart C, Dempfle A, Plagens A, Seifart U, et al. (2005). TNF-alpha-, TNF-beta-, IL-6-, and IL-10-promoter polymorphisms in patients with chronic obstructive pulmonary disease. Tissue Antigens 65: 93-100.

Shields PG, Caporaso NE, Falk RT, Sugimura H, et al. (1993). Lung cancer, race, and a CYP1A1 genetic polymorphism. Cancer Epidemiol. Biomarkers Prev. 2: 481-485.

Takabatake N, Nakamura H, Abe S, Inoue S, et al. (2000). The relationship between chronic hypoxemia and activation of the tumor necrosis factor-alpha system in patients with chronic obstructive pulmonary disease. Am. J. Respir. Crit. Care Med. 161: 1179-1184.

Tanaka G, Sandford AJ, Burkett K, Connett JE, et al. (2007). Tumour necrosis factor and lymphotoxin A polymorphisms and lung function in smokers. Eur. Respir. J. 29: 34-41.

Tanni SE, Pelegrino NR, Angeleli AY, Correa C, et al. (2010). Smoking status and tumor necrosis factor-alpha mediated systemic inflammation in COPD patients. J. Inflamm. 7: 29.

Tefre T, Ryberg D, Haugen A, Nebert DW, et al. (1991). Human CYP1A1 (cytochrome P(1)450) gene: lack of association between the Msp I restriction fragment length polymorphism and incidence of lung cancer in a Norwegian population. Pharmacogenetics 1: 20-25.

Teramoto S, Ishii T, Ishii M, Yamamoto H, et al. (2008). Variation in the tumour necrosis factor-alpha gene is not associated with susceptibility to Asian COPD. Eur. Respir. J. 31: 682-683.

Genetics and Molecular Research 13 (2): 3209-3217 (2014)

CFUNPEC-RP www.funpecrp.com.br 
Wilson AG, Symons JA, McDowell TL, McDevitt HO, et al. (1997). Effects of a polymorphism in the human tumor necrosis factor alpha promoter on transcriptional activation. Proc. Natl. Acad. Sci. U. S. A. 94: 3195-3199.

Wouters EF, Reynaert NL, Dentener MA and Vernooy JH (2009). Systemic and local inflammation in asthma and chronic obstructive pulmonary disease: is there a connection? Proc. Am. Thorac. Soc. 6: 638-647.

Wu WS and McClain KL (1997). DNA polymorphisms and mutations of the tumor necrosis factor-alpha (TNF-alpha) promoter in Langerhans cell histiocytosis (LCH). J. Interferon. Cytokine Res. 17: 631-635.

Zhan P, Wang J, Wei SZ, Qian Q, et al. (2011). TNF-308 gene polymorphism is associated with COPD risk among Asians: meta-analysis of data for 6,118 subjects. Mol. Biol. Rep. 38: 219-227.

Zhang S, Wang C, Xi B and Li X (2011). Association between the tumour necrosis factor-alpha-308G/A polymorphism and chronic obstructive pulmonary disease: an update. Respirology 16: 107-115.

Zhou SF, Liu JP and Chowbay B (2009). Polymorphism of human cytochrome P450 enzymes and its clinical impact. Drug Metab. Rev. 41: 89-295. 